\title{
THE SYMPATHETIC STRIKE
}

\author{
By C. O. Pratt,
}

Chairman, General Executive Board of Amalgamated Association of Street and Electric Railway Employees of America.

The sympathetic strike judiciously used is a potent weapon for good. Arbitrarily used it is dangerous and would result in a calamity. Self-preservation is the first law of nature. In order that the smallest amount of injustice may result we have a government which is supposed to guarantee equal rights to all and special privileges to none, and every citizen is guaranteed the right to life, liberty and the pursuit of happiness. The centralization of wealth in the hands of unscrupulous employers who have studiously entrenched themselves, has changed these conditions to the extent that the interests of individuals are entirely lost sight of. Instead of a government of the people, by the people and for the people we discover, in some instances at least, that we have incompetent municipal officials who are as putty in the hands of those who mold and control them for the benefit of private interests.

As an illustration of a condition that warrants a general strike, the recent street car strike of Philadelphia affords an example. The political and transit interests in this city are so interwoven that each has tried to serve the other's interest regardless of the rights of the people. A year ago the street car men of this city established a union for their elevation and self-preservation. The political interests immediately sought to control the votes of these men and use them as an asset to their political intrenchment. Paid spies and detectives were worked into the union, but notwithstanding all the efforts made, the carmen were not to be controlled. Because of this, immediate plans were begun to exterminate the union and its leaders who were unwilling to surrender their political freedom and become a part of a machine which has for its purpose the perpetuation of its political power and domination.

To sum up the situation briefly, it can best be described by a statement that I am creditably informed was made by a representative of the political-transit interests prior to the strike. "The car(39I) 
men's union is going to be exterminated. We have been successful in electing a district attorney and the courts are at our disposal. The city administration is absolutely with the company and the cars will be run even if necessary to man them with the firemen and policemen. The state constabulary is also at our command and the newspapers have been bought up. Througl the company's press agent we have discredited the carmen's union with the people and they will not have public sympathy. We are going to force the strike at a time of the year when the weather is most inclement and that will further incense the people against the carmen and they will also practically be compelled to ride in the cars."

The company's secret detective force, augmented by the city's detective force attempted bribery, intimidation and coercion. Kidnapping and spiriting to Moyamensing Prison in order to discredit and besmirch the character of the carmen's representatives were also resorted to. This was the elaborate programme mapped out and worked out for weeks before the strike took place. Trickery and treachery were resorted to in attempting to negotiate a settlement that would of itself destroy the union without a strike. Finally, wholesale discharges of the oldest and best employees of the company "for the good of the service" forced a lockout. Imported armed thugs by the trainload were dumped into the city to incite riot and to shoot to kill. It is currently reported that practically the entire Pinkerton detective force was also turned loose, the state constabulary were brought in, "Brownie" policemen were recruited from Bowery and Tenderloin districts, and well-known thugs and crininals were uniformed and given guns and clubs.

The manufacturers and merchants and business men's associations all over the country poured in telegrams endorsing the gigantic conspiracy of the political-transit combination, pledging moral and financial support and commending the company in their refusal to arbitrate. Polished perjury by men of high rank was indulged in an effort to misrepresent the strikers and place them in a false position before the public. This was a part of the gigantic "sympathetic" combine of capitalists, employers and professional politicians who were determined to destroy every vestige of the carmen's union.

It was an unequal contest for one organization of labor to meet single-handed, deprived of every weapon of defense, and practically pinioned as a target for a hired band of strikebreakers who were put 
upon the cars, and the city's blue-coated police, wrongly called minions of the law. There was a total disregard of the rights of the people by the city officials, who ignored and violated their oath of office (notwithstanding the fact that the city has a contract with the traction company, which makes every citizen an interested party to a controversy which involves their welfare). After a week of most cruel and unwarranted strife, there was an open revolt on the part of the wage-earners, organized and unorganized alike.

Why should not the wheels of industry be stopped in the face of such a conspiracy as this? Should working men and women continue at the wheel and turn out profits for their employers to be handed over to the gangsters for the purpose of destroying their fellowworkers and simply await their turn to be selected for the sacrifice later on?

It is claimed in their last year's report that the United States Steel Corporation realized a profit of $\$ 600$ as an average off of each of their employees, yet a large percentage of their employees receive less than $\$ 500$ for their entire year's labor. How can a wage-earner support a family decently on that amount? Surely he cannot afford to give from that small pittance to assist a fellowman on strike. The employer takes all of the profits and, therefore, so long as his business is not interfered with he can contribute that profit to another employer who has a strike on his hands. When the wheels of industry are stopped the profits to the employers cease, they then have financial losses of their own to meet and cannot give money to another employer to assist in destroying a labor union and forcing down wages.

The general strike in Philadelphia was a decided st1ccess. Without it the carmen would have failed. Public sentiment would have died out, for the people would never have understood the true facts as there was not a newspaper in this city that ever published them. It was an educational movement that enlightened the people to an extent that could not otherwise have been done. They witnessed the desecration of the stars and stripes by the city police. They saw innocent people arrested and railroaded through the courts. Drivers were not permitted to carry passengers in their vehicles. Meeting halls were raided and wholesale arrests were made without right or reason. They saw city officials deny the people their constitutional rights, defy and set aside all law, and prostitute their oath of office. 
The general strike was positive evidence before the world of the justice of the carmen's cause, and there was no other way by which this fact could be established. The truth of the actual conditions became generally known and understood. It was a test and an evidence of the loyalty of the working class of people to the principles of our republican form of government, and proved conclusively that they can be depended upon to defend justice and right and the preservation of our constitutional liberty against any foe.

Our forefathers acted in sympathy when they threw off the yoke of tyranny and fought for the establishment of a government of the people, by the people and for the people. Our own fathers, many of them, fron ' 61 to ' 65 did not stop to ask if they had contracts with their employers when they went to the front to fight for the preservation of the union and eventually the freeing of the chattel slave. Nor did they stop to question whether such an action would injure a friendly employer. There was a paramount issue involved which surmounted all other questions that were insignificant in comparison. So it was in this strike. The combined employing interests, controlled by a corrupt political ring which deals out special privileges to one class and attempts to terrorize the other, demanded the complete surrender of the rights of the working class. In this they failed, and their failure was due to the sympathetic or general strike, the fruits of which are yet to be more fully realized.

It is true that the innocent often times suffer with the guilty, but the object is to obtain the greatest good for the greatest number. The chattel slave owners were made to suffer and were financially ruined. The wage slave owners of to-day are often more brutal and intolerant than were the chattel slave owners. The system may operate differently, paid spies, the blacklist and the prison are used, while the professional strikebreaker acts as the modern slave driver armed with blackjack and gun instead of the rawhide and the whipping-post of former days.

A strike can best be settled before it actually occurs. If the employers and the emt loyees are not sufficiently broad-minded to meet in conference and work out a satisfactory adjustment of differences, then voluntary arbitration should be entered into. Especially is this true where a quasi-public corporation is involved 
which affects the entire community. If let alone the Philadelphia Rapid Transit Company would never have permitted this strike to take place, but under the political lash they were compelled to say "there is nothing to arbitrate." The director of public safety is a heavy stockholder in this company. Why should he not use his public office to protect his private interests, politically as well as financially? Other politicians are deeply concerned in the financial interests of the Philadelphia Rapid Transit Company. The official head of the city was quoted as not believing in arbitration, either in the settlement of industrial disputes or in disputes between nations-that they must be fought out. A so-called contract exists between the Philadelphia Rapid Transit Company and the city, which permits the city to have three directors upon the company's board of directors, the mayor is one, George H. Earle, Jr., was another and William H. Carpenter a third. None of these men ever advocated or urged arbitration.

Net results, thirty innocent lives crushed out under the wheels of cars that were operated by incompetent and unskilled men. No one knows how many hundreds of accidents occurred that will cripple or maim people for life, nor is it known how many were shot and killed during the strife. Some one is responsible for that senseless strike, and the wanton sacrifice of life. Nothing was gained by the company or the political interests. Indeed, both are in worse repute and both on the verge of political as well as financial bankruptcy. The carmen's union is back to work for the company without having sacrificed its political freedom. The great civic awakening caused by the general strike is yet to be taken into account. The benefits that will result therefrom will be immeasurable. Organized labor in this city has been increased by at least 20,000 members and the work is still continuing with rapid progress. Wages throughout the entire community have been advanced, and other employers have modified and improved working conditions to an extent unequaled at any previous time. Unionism was placed on trial. All over the country unionism was victorious. No demands were made upon the traction company by the carmen, no question of new conditions was involved. It was the breaking of a contract by the company made and entered into by the two contending parties last June. It was a prearranged lockout of the union. Senator $\mathrm{McNichol}$ and the Mayor had pledged that if the June con- 
tract would be accepted by the carmen at that time that they would guarantee its fulfilment by the company. What a reflection upon their guarantee! What a double cross!

A thorough organization of labor directed by wise and conservative leadership is the strongest fortification that can be established for the preservation of our republican form of government. It is the strongest guarantee that our constitutional liberties will be protected and perpetuated. Without such an effective balance of power we will become a judicial monarchy controlled by selfish moneyed interests that will lead the nation back to the oppression and tyranny that our forefathers fought against and from which they successfully escaped. 